\title{
EPMA of Amphibole in Meteorites: Nakhlite Northwest Africa 13368 and Winonaite Northwest Africa 13432
}

\author{
Paul Carpenter ${ }^{1}$, Anthony Irving ${ }^{2}$ and Bradley Jolliff ${ }^{3}$ \\ ${ }^{1}$ Washington University in St. Louis, Saint Louis, MO, Missouri, United States, ${ }^{2}$ Univesity of Washington, \\ United States, ${ }^{3}$ Washington University St Louis, Saint Louis, MO, Missouri, United States
}

We report on electron-probe microanalysis (EPMA) of amphibole in Martian nakhlite Northwest Africa (NWA) 13368, which contains potassic-chloro-hastingsite (KCH), and winonaite NWA 13432, which contains fluoro-edenite (FE) [1]. Amphiboles are difficult to recognize as they are rare in meteorites, are present typically as micron-sized crystals, and have backscattered-electron (BSE) contrast that is similar to other silicates. The meteorites were studied using BSE imaging, X-ray mapping, and quantitative analysis using the JEOL JXA-8200 electron microprobe and the Probe for EPMA operating system at Washington University. Wavelength-dispersive spectrometry (WDS) was used for quantitative analysis with mean atomic number (MAN) background correction, except for fluorine which used a polynomial background fit due to background curvature, and correction for interference from the Fe L $\alpha$ X-ray line. The general amphibole stoichiometric formula is $\mathrm{A} \mathrm{B}_{2} \mathrm{M}_{5} \mathrm{~T}_{8} \mathrm{O}_{22} \mathrm{X}_{2}$ and the formulas and classification were calculated using the Excel sheet of Locock [2] and are listed in Table 1.

Martian nakhlite NWA 13368 is composed predominantly of euhedral, prismatic cumulus grains of augite with ferroan rims, subordinate larger grains of olivine, and sparse blocky grains of titanomagnetite, with a fine grained intercumulus assemblage of cruciform titanomagnetite, fayalite, hedenbergite, silica polymorph, pyrrhotite, and alkali feldspathic glass. The augite crystals have melt inclusions which contain $\mathrm{KCH}$ amphibole (Fig. 1A and 1B). The mineral chemistry is as follows: augite cores Fs23.0-24.7 Wo36.7-37.6, Mg\# 59-64\%, and strongly zoned rims Fs46.7-52.9 Wo44.2-33.8, Mg\# 14-16\%. Olivine cores are Fa61.5-62.7, and rims Fa65-88.6. The intercumulus region contains hedenbergite Fs50.6-53.5 Wo41.2-40.6, fayalite Fa92.6-92.7, and an alkali feldspathic glass. Based on mineral chemistry, augite zoning profiles, and modal abundances, NWA 13368 is similar to MIL 03346 and paired specimens from Miller Range, Antarctica [3].

The $\mathrm{KCH}$ amphibole has a high concentration of $\mathrm{X}$-site $\mathrm{Cl}$ and elevated $\mathrm{K}$ and $\mathrm{Fe}$ (Table 1). Analyses of the amphibole from six melt inclusions have a uniform composition, and match analyses of $\mathrm{KCH}$ from inclusions in MIL 03346 [4,5]. The accommodation of $\mathrm{Cl}$ in the amphibole X-site is considered to be a function of $\mathrm{Fe} / \mathrm{Mg}$, tetrahedral Al, and A-site $\mathrm{K}$ based on analysis of natural and synthetic amphiboles, so that $\mathrm{Cl}$ preferentially occupies the $\mathrm{X}$-site rather than $\mathrm{OH}$ or $\mathrm{F}[6,7]$. Apatite from melt inclusions and intercumulus regions contains both $\mathrm{F}$ and $\mathrm{Cl}$ but the $\mathrm{KCH}$ has very low $\mathrm{F}$, suggesting that the $\mathrm{KCH}$ partition coefficient for $\mathrm{Cl}$ is higher than observed for other bulk compositions [8], and that apatite records F content more effectively. Melt inclusions record an Fe-enrichment trend during crystallization. The $\mathrm{Mg \#}$ is 60 in augite adjacent to the inclusion, 38 for transitional augite, 15 for ferroan augite on the interior inclusion wall, and 3-9 for $\mathrm{KCH}$. This enrichment within a melt inclusion is similar to the range in augite rim zoning profiles. The $\mathrm{Cl}$ content of inclusion glass is $10 \mathrm{X}$ higher than in the intercumulus glass and indicates high enrichment of $\mathrm{Cl}$ occurred during crystallization of the nakhlite melt.

Winonaite NWA 13432 has a metamorphic texture with pervasive triple grain junctions, and is an aggregate of olivine, orthopyroxene, amphibole, sodic plagioclase, diopside and kamacite, plus minor fluorapatite, graphite and schreibersite. A cluster classification map based on quantitative EPMA mapping shows the phase relations (Fig. 1C). The mineral chemistry is as follows: olivine Fa3.0-3.3, orthopyroxene Fs3.5-3.8 Wo1.71.9, diopside Fs1.1-1.3 Wo44.8-45.8, and plagioclase An20.8 Ab76.5 Or2.6. The amphibole has a high concentration of $\mathrm{F}$ with very low $\mathrm{Cl}$ (Table 1), is classified as a fluoro-edenite (FE), and is similar to that from winonaiteHammadah al Hamra $(\mathrm{HaH}) 193$ [9]. In both meteorites the FE is associated with diopside, olivine, orthopyroxene, and plagioclase, and is thought to have formed by replacement of diopside via the reaction 
diopside + plagioclase + olivine $=$ edenite. This reaction is substantiated by observation of FE associated with diopside and modal variation in plagioclase.

The amphibole halogen contents exemplify the association of $\mathrm{Cl}$ with $\mathrm{Fe}$-rich, and $\mathrm{F}$ with $\mathrm{Mg}$-rich bulk compositions. The amphibole composition apparently exerts unit cell constraints on X-site halogen occupancy, thus controlling the halogen species and concentration. A feedback mechanism of $\mathrm{Cl}$ affecting $\mathrm{Fe}$ and $\mathrm{K}$ incorporation has also been proposed [6,10]. $\mathrm{KCH}$ from augite melt inclusions in nakhlite NWA 13368 contains an average of $6.28 \mathrm{wt} \% \mathrm{Cl}$ and $\mathrm{F}$ is below detection. Micron-sized apatite in the augite melt inclusions contains $0.5 \mathrm{wt} \% \mathrm{~F}, 0.2-0.4 \mathrm{wt} \% \mathrm{Cl}$, and 0.1-0.3 calculated $\mathrm{wt} \% \mathrm{OH}$, and thus has a higher $\mathrm{F}$ content compared to the $\mathrm{KCH}$. Apatite from the intercumulus region contains $0.8 \mathrm{wt} \% \mathrm{~F}$ and $0.2 \mathrm{wt} \% \mathrm{Cl}$ with no calculated $\mathrm{OH}$. Inclusion glass contains $0.5 \mathrm{wt} \% \mathrm{Cl}$ compared to $0.04 \mathrm{wt} \%$ in the intercumulus glass. The $\mathrm{KCH}$-bearing augite melt inclusions thus appear to have recorded considerably higher $\mathrm{Cl}$ during the intermediate phase of augite crystallization. FE from NWA 13432 contains $4.34 \mathrm{wt} \% \mathrm{~F}$ and $0.07 \mathrm{wt} \% \mathrm{Cl}$, and apatite contains $3.38 \mathrm{wt} \% \mathrm{~F}$ and $1.70 \mathrm{wt} \% \mathrm{Cl}$, which reflects the normal preferred incorporation of $\mathrm{F}$ vs. $\mathrm{Cl}$ in the amphibole $\mathrm{X}$-site. Apatite is present in trace amount in NWA 13432, so it cannot be the source for F. We suggest that a F-bearing fluid phase has permeated portions of the winonaite body and leaves a record in the amphibole halogen chemistry.

In conclusion, the major element and halogen chemistry of amphibole provides insight into both magmatic and metamorphic processes as recorded by meteorites.
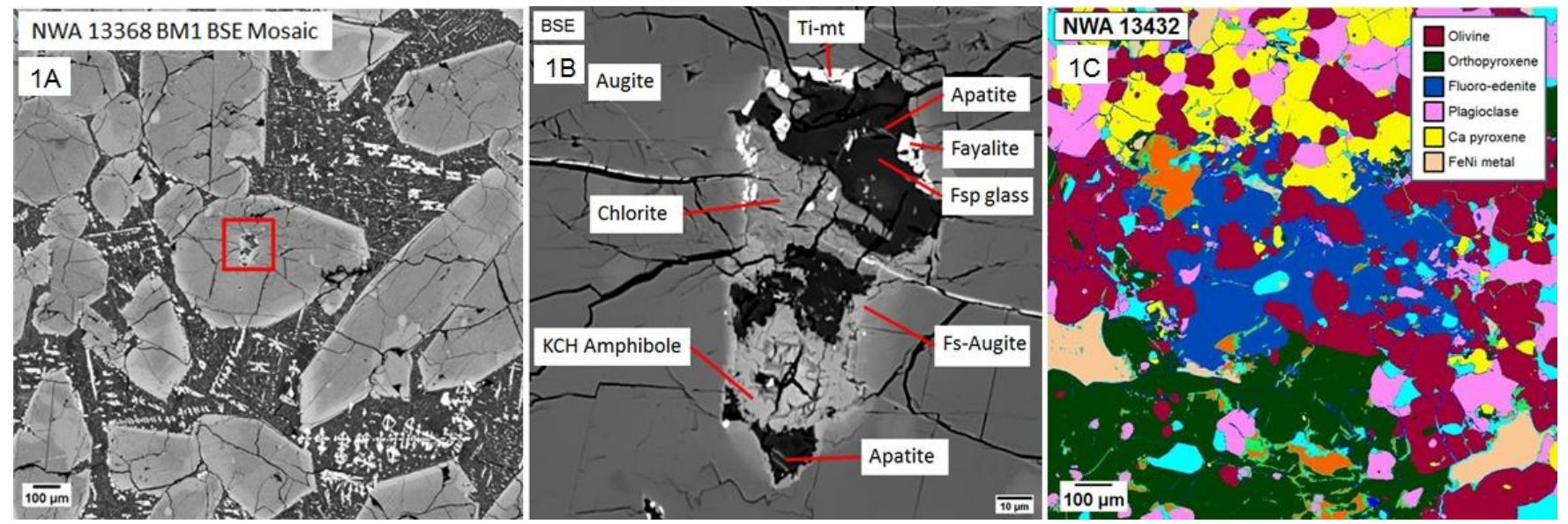

Figure 1. 1A BSE image of nakhlite NWA 13368 showing cumulus augite with ferroan zoned rims, highlighted melt inclusion, and cumulus region between augite crystals. 1B Higher magnification BSE image of augite melt inclusion containing $\mathrm{KCH}$ amphibole. 1C Quantitative X-ray cluster map of winonaite NWA 13432 showing FE amphibole in blue, diopside in yellow, plagioclase in pink, olivine in red, and orthopyroxene in dark green. 


\begin{tabular}{|c|c|c|c|c|c|c|c|c|}
\hline \multirow[t]{3}{*}{ Table 1} & \multicolumn{4}{|c|}{ Potassic-chloro-hastingsite } & \multicolumn{4}{|c|}{ Fluoro-edenite } \\
\hline & \multicolumn{2}{|c|}{ NWA 13368} & \multicolumn{2}{|c|}{ MIL 03346} & \multicolumn{2}{|c|}{ NWA 13432} & \multicolumn{2}{|c|}{ HaH 193} \\
\hline & $n=33$ & SD & $n=14$ & $n=1$ & $n=53$ & SD & $A, n=6$ & $B, n=17$ \\
\hline $\mathrm{SiO}_{2}$ & 35.67 & 1.33 & 37.48 & 35.60 & 50.10 & 0.71 & 49.7 & 50.03 \\
\hline $\mathrm{TiO}_{2}$ & 0.44 & 0.48 & 0.38 & 0.24 & 1.00 & 0.14 & 0.63 & 1.08 \\
\hline $\mathrm{Al}_{2} \mathrm{O}_{3}$ & 10.69 & 1.35 & 8.62 & 10.40 & 6.61 & 0.26 & 5.89 & 5.88 \\
\hline $\mathrm{Cr}_{2} \mathrm{O}_{3}$ & 0.02 & 0.03 & & & 0.36 & 0.05 & 0.38 & 0.62 \\
\hline $\mathrm{FeO}$ & 30.90 & 1.12 & 31.95 & 32.70 & 0.77 & 0.07 & 1.08 & 1.25 \\
\hline MnO & 0.36 & 0.05 & 0.36 & 0.21 & 0.06 & 0.06 & 0.08 & 0.09 \\
\hline MgO & 1.16 & 0.29 & 0.97 & 0.71 & 23.19 & 0.01 & 22.80 & 23.3 \\
\hline $\mathrm{CaO}$ & 10.23 & 0.46 & 9.23 & 10.10 & 11.76 & 0.15 & 11.40 & 11.2 \\
\hline $\mathrm{Na}_{2} \mathrm{O}$ & 1.07 & 0.14 & 0.76 & 0.94 & 3.76 & 0.06 & 3.88 & 4.09 \\
\hline $\mathrm{K}_{2} \mathrm{O}$ & 3.08 & 0.19 & 2.52 & 3.27 & 0.57 & 0.06 & 0.45 & 0.48 \\
\hline $\mathbf{P}_{2} \mathbf{O}_{5}$ & 0.28 & 0.29 & 0.18 & 0.50 & 0.01 & 0.01 & & \\
\hline $\mathbf{F}$ & nd & & 0.18 & & 4.34 & 0.06 & 4.05 & 4.56 \\
\hline $\mathrm{Cl}$ & 6.28 & 0.35 & 5.01 & 6.23 & 0.07 & 0.01 & 0.04 & nd \\
\hline $\mathrm{O}=\mathrm{F}, \mathrm{Cl}$ & 1.42 & & & 1.41 & 1.85 & & 1.71 & 1.92 \\
\hline Total & 98.76 & & 97.78 & 99.50 & 100.76 & & 98.7 & 100.6 \\
\hline Note & $\begin{array}{l}\text { nd }=\text { not } \\
\text { detected }\end{array}$ & & $\begin{array}{l}\text { Sautter } \\
\text { et al. } 2006\end{array}$ & $\begin{array}{l}\text { McCubbin } \\
\text { et al. } 2009\end{array}$ & & & $\begin{array}{l}\text { Flosset } \\
\text { Sections }\end{array}$ & $\begin{array}{l}\text { al. } 2007 \\
\text { sA and B }\end{array}$ \\
\hline \multicolumn{9}{|c|}{$\begin{array}{l}\text { NWA } 13368 \text { potassic-chloro-hastingsite, formula A B } \mathrm{M}_{5} \mathrm{~T}_{8} \mathrm{O}_{22} \mathrm{X}_{2} \text {, A sum 0.939, B sum 2, M sum 5, T sum 8, } \mathrm{X} \text { sum } 2 \\
{\left[\mathrm{~K}_{0.669} \mathrm{Na}_{0.27}\right]\left[\mathrm{Ca}_{1.867} \mathrm{Na}_{0.083} \mathrm{Mn}_{0.05}\right]\left[\mathrm{Fe}^{2+}{ }_{3.732} \mathrm{Fe}^{3+}{ }_{0.67} \mathrm{Mg}_{0.295} \mathrm{Al}_{0.242} \mathrm{Ti}_{0.056} \mathrm{Cr}_{0.003} \mathrm{Mn}^{2+}{ }_{0.002}\right]\left[\mathrm{Si}_{6.076} \mathrm{Al}_{1.904} \mathrm{P}_{0.02}\right] \mathrm{O}_{22}\left[\mathrm{Cl}_{1.813} \mathrm{OH}_{0.187}\right]}\end{array}$} \\
\hline \multicolumn{9}{|c|}{$\begin{array}{l}\text { NWA } 13432 \text { fluoro-edenite, formula } A B_{2} \mathrm{M}_{5} \mathrm{~T}_{8} \mathrm{O}_{22} \mathrm{X}_{2}, \mathrm{~A} \text { sum } 0.921 \text {, B sum } 1.999, \mathrm{M} \text { sum } 4.999, \mathrm{~T} \text { sum 8, } \mathrm{X} \text { sum } 1.999 \\
{\left[\mathrm{Na}_{0.82} \mathrm{~K}_{0.101}\right]\left[\mathrm{Ca}_{1.747} \mathrm{Na}_{0.191} \mathrm{Fe}^{2+}{ }_{0.041} \mathrm{Mg}_{0.013} \mathrm{Mn}_{0.007}\right]\left[\mathrm{Mg}_{4.781} \mathrm{Ti}_{0.104} \mathrm{Fe}^{3+}{ }_{0.048} \mathrm{Cr}_{0.039} \mathrm{Al}_{0.027}\right]\left[\mathrm{Si}_{6.947} \mathrm{Al}_{1.053}\right] \mathrm{O}_{22}\left[\mathrm{~F}_{1.903} \mathrm{OH}_{0.08} \mathrm{Cl}_{0.016}\right]}\end{array}$} \\
\hline
\end{tabular}

Figure 2. Table 1. Left side: EPMA average analysis of $\mathrm{KCH}$ amphibole from nakhlite NWA 13368 and comparison to $\mathrm{KCH}$ from nakhlite MIL 03346. Right side: FE from winonaite NWA 13432 and comparison to FE from two sections $\mathrm{A}$ and $\mathrm{B}$ of winonaiteHaH 193. Amphibole stoichiometric formulas are shown at the bottom of the table.

References

[1] Carpenter P. et al., 52nd LPSC, \#2329, 2021.

[2] Locock, A.J., Comp. Geosci. 62, 1-11, 2014.

[3] Met. Bull. 89, 2005.

[4] Sautter V. et al., Earth Planet. Sci. Letters, 252, 45-55, 2006.

[5] McCubbin F.M. et al., (2009) Geochim. Cosmochim. Acta, 73, 4907-4917, 2009.

[6] Henry, D.J. and Daigle N.M., Am. Min., 103, 55-68, 2018.

[7] Jenkins, D.M., Am. Min., 104, 514-524, 2019.

[8] Filiberto J. and TreimanA.H,. Geology, 37, 1087-1090, 2009.

[9] Floss C. et al. Am. Min., 92, 460-467, 2007.

[10] Geisting P. and Filiberto J., Meteoritics Planet. Sci., 51, n11, 2127-2153, 2016 